\title{
Biologic disease-modifying anti-rheumatic drugs and kinase inhibitors: differences in efficacy and safety in rheumatoid arthritis
}

\author{
Roy Fleischmann ${ }^{1,2} \mathbb{0}$
}

Received: 14 September 2021 / Revised: 17 September 2021 / Accepted: 20 September 2021 / Published online: 24 September 2021

(c) International League of Associations for Rheumatology (ILAR) 2021

To determine relative efficacy of two molecules, the gold standard is a well-designed head-to-head randomized clinical trial (RCT) comparing the two with a validated and clinically meaningful primary endpoint. An alternate method, which may have inherent bias complicating the interpretation of results, is comparing the efficacy of both molecules against a common comparator in a RCT using a validated primary endpoint. The biases in such comparisons are numerous: the trials compared most likely were conducted in different investigative sites and in different regions of the world with different patients and perhaps significant differences in patient baseline demographics and inclusion-exclusion criteria, amongst other confounders. Despite the potential of bias, such an analysis should provide a sense of relative effectiveness of the two molecules, especially if similar results are seen repeatedly. A third comparison is to ascertain the effectiveness of a molecule in patients who failed to adequately respond to the first molecule. This comparison is also open to similar bias as well as selection bias-why was the first molecule utilized rather than the second?

Although it is fashionable to perform a meta-analysis to assess relative efficacy, meta-analyses are also hampered by significant differences in the patient populations studied as well as potentially missing critical information $[1,2]$. The use of "real-world" registries for such comparisons may well also give misleading or conflicting results as there can be significant bias on multiple levels, including selection bias and missing clinically relevant data.

For these reasons, it is reasonable to examine the relative clinical efficacy of Janus kinase inhibitors (jakinibs, JAKi)

Roy Fleischmann

rfleischmann@arthdocs.com

1 Department of Medicine, University of Texas Southwestern Medical School, Dallas, TX, USA

2 Metroplex Clinical Research Center, 8144 Walnut Hill Lane, Suite 810, Dallas, TX 75231, USA compared to biologic disease-modifying anti-rheumatic drugs (bDMARDs) by evaluating well-conducted and powered RCT in rheumatoid arthritis (RA), as there is a wealth of peer-reviewed data available involving head-to-head RCT with a similar comparator and RCT of jakinibs after failure of a bDMARD.

The primary endpoint in a head-to-head study in RA should be a validated metric showing a meaningful clinical response or a meaningful depth of response. Several metrics have been shown to effectively discriminate between two molecules. The standard is the American College of Rheumatology response criteria (ACR20/50/70), but one can also investigate change in the Disease Activity Score in 28 joints (DAS28) and the Clinical Disease Activity Index (CDAI). The ACR20 has been shown to be the most suitable metric discriminating an effective medication from placebo [3]. In comparing two effective medications to each other, the most suitable discriminators are deeper responses such as the ACR50/70, CDAI reduction of $85 \%$, or comparison of the reduction of the DAS28 [4]. One can also assess the percent of patients achieving a disease state such as CDAI, Simple Disease Activity Scale (SDAI), or DAS28(ESR) remission or low disease activity [4]. Although there is a discrepancy in the cut-points for LDA and remission using the DAS28(CRP) versus the DAS28(ESR), many studies use the same cut-points, although inappropriately [5].

We will focus on four targeted synthetic disease-modifying anti-rheumatic drugs (tsDMARDs, jakinibs) approved for the treatment of RA: tofacitinib, baricitinib $(2 \mathrm{mg})$, and upadacitinib were approved in the USA; these 3 , including baricitinib $4 \mathrm{mg}$, and filgotinib were approved by the European Medicines Agency and in Japan. There are multiple biologic disease-modifying anti rheumatic drugs (bDMARDs) approved worldwide: tumor necrosis factor inhibitors (TNFi, etanercept, adalimumab, infliximab, certolizumab pegol, and golimumab), Interleukin 6 inhibitors (IL6i) (tocilizumab and sarilumab), the co-stimulatory molecule (abatacept), and a B cell modulator (rituximab). 
There have been four properly powered head-to-head RCT in RA comparing a jakinib plus continued methotrexate (MTX) to a TNFi (adalimumab $40 \mathrm{mg}$ every other week plus MTX) in patients with continued disease activity despite MTX. In three of these, the jakinib was found to be superior to adalimumab in achieving the primary endpoint: baricitinib $4 \mathrm{mg}$ (ACR20 at week 12), upadacitinib $15 \mathrm{mg}$ (ACR50) at month 6, and filgotinib $200 \mathrm{mg}$ (DAS28 < 2.6 at month 3) [6-8]. In the fourth, tofacitinib $5 \mathrm{mg}$ BID plus MTX was found to be non-inferior to adalimumab plus MTX [9]. There was an additional head-to-head study comparing upadacitinib $15 \mathrm{mg}$ to intravenous abatacept in a similar population which found that upadacitinib was superior to abatacept in achieving reduction in the DAS28(CRP) by week 12 [10]. These RCT also demonstrated that multiple secondary endpoints showed at least numerical, if not statistical, superiority versus the comparator bDMARD including ACR20/50/70 responses, improvement in DAS28 and CDAI, and achieving effective disease control including low disease (LDA) and remission [6-8, 10].

With respect to patient-reported outcomes (PRO), each jakinib demonstrated numerical if not statistically significant improvement in multiple PRO versus adalimumab $[6-9,11-14]$ and upadacitinib to abatacept [10]. Three trials assessed radiographic progression-no differences were seen comparing the jakinib to adalimumab [6-8].

When assessing relative efficacy to a common comparator, multiple RCT have compared either a jakinib or a bDMARD as monotherapy to MTX, in patients who were naïve to MTX. The trials with tofacitinib, baricitinib (4 mg), and upadacitinib all demonstrated superiority in achieving ACR responses, reduction in DAS28, multiple metrics of remission and LDA, improvement in multiple PRO, and reduction in radiographic progression with the jakinib compared to MTX in this population [15-17]. A similar trial with filgotinib failed to achieve its primary endpoint, but multiple secondary endpoints were reached [18]. Of the bDMARDs approved for RA, only tocilizumab achieved similar results [19]. RCT of etanercept, adalimumab, golimumab, and abatacept demonstrated no difference in clinical efficacy versus MTX [20-23]. There have not been comparable RCT with infliximab, certolizumab pegol, or sarilumab. One can therefore conclude that jakinibs are superior to a common comparator (MTX), while bDMARDs, except for tocilizumab, are not.

Placebo-controlled RCT have been conducted with each of the jakinibs in patients who had an inadequate response or could not tolerate bDMARDs. The results indicate that many of these patients do respond to the jakinib utilizing metrics such as ACR responses [24-28]. There are two trials in TNFi inadequate responders utilizing a second TNFi which showed clinical efficacy, but not as high as a jakinib after a bDMARD $[29,30]$. Although this evidence is admittingly weaker than a true head-to-head comparison, this does suggest additional evidence of superior clinical efficacy of jakinibs. It should be strongly stressed that the results shown here pertain to groups of patients and that in groups of patients, there appears to be a higher likelihood of responding to a jakinib as opposed to a bDMARD. Importantly however, there are patients who will respond appropriately to a bDMARD rather than a jakinib as shown in the pre-specified extension in SELECT-COMPARE which evaluated responses with adalimumab in patients who did not have a response or reach LDA with upadacitinib [27].

Thus, the evidence suggests that there is a clinical advantage of jakinibs over bDMARDs after MTX, versus MTX, and in patients who are intolerant or do not achieve an adequate response to a bDMARD. But that is not the whole story; one must consider the safety profile of the molecules as well to understand the true benefit versus risk.

Each of the studies referenced evaluated safety as well as efficacy. Clearly, the same adverse events can occur with jakinibs and bDMARDs, but the frequency of adverse events, especially medically important events, are different. For example, it is well-known that there are numerically more cases of herpes zoster, gastrointestinal perforations, lymphopenia, neutropenia, anemia and elevated creatine phosphokinase, liver function test abnormalities, lipids, and serum creatine with jakinibs compared to bDMARDs. bDMARDs, especially monoclonal TNFi, have a higher risk of activation of latent tuberculosis, demyelinating disease exacerbation, worsening heart failure, and lupus-like syndrome.

The recent completion of a study evaluating the safety of tofacitinib versus TNFi in patients over the age of 50 with at least one cardiovascular risk factor has not been published in a peer-reviewed journal at the time of this editorial. However, results have been published on the European Medicines Agency (EMA) website which revealed that although the incidence rates of major adverse cardiac events (MACE), malignancy, mortality, and venous thrombotic episodes were low for both MOA, there was a numerical difference favoring the TNFi which was not statistically significant [31] (https://www.ema.europa.eu/en/documents/referral/xelja nz-h-20-1485-c-4214-0017-assessment-report-article-20_ en.pdf). From these reports, one can calculate the number needed to harm $(\mathrm{NNH})$ : one would have to treat over 275 more patients with tofacitinib $5 \mathrm{mg}$ BID to have one more malignancy than with a TNFi and over 500 more for one MACE. Nevertheless, the results indicate that jakinibs are not quite as safe with respect to these events as a TNFi in this high risk population.

In summary, the clinical benefit of a jakinib versus a bDMARD in RA favors a jakinib in a group of patients, but numerically more medically important events occur with a jakinib. In many patients, the convenience of a jakinib and its benefits outweigh the risks, but it is up to the practitioner 
and the patient as to which MOA is the preferred first choice. Clearly, if the first choice fails to provide adequate benefit or is not tolerable, switching to the alternate MOA is reasonable-both jakinibs and bDMARDs are effective medications with a reasonable risk-benefit profile.

\section{Declarations}

Conflict of interest Consultant or Clinical Trial grants for: AbbVie, Amgen, BMS, Janssen, Eli Lilly, Genentech, Gilead, Pfizer, Roche, Sanofi-Aventis, UCB

\section{References}

1. Catala-Lopez F, Tobias A, Cameron C, Moher D, Hutton B (2014) Network meta-analysis for comparing treatment effects of multiple interventions: an introduction. Rheumatol Int 34(11):1489-1496. https://doi.org/10.1007/s00296-014-2994-2

2. Roundtree A, Kallen M, Lopez-Olivo M, Kimme B, Skidmore B, Ortiz Z, Cox V, Suarez-Almazor M (2009) Poor reporting of search strategy and conflict of interest in over 250 narrative and systematic reviews of two biologic agents in arthritis: a systematic review. J Clin Epidemiol 62(2):128-137. https://doi.org/10.1016/j. jclinepi.2008.08.003

3. Felson DT, Anderson JJ, Boers M, Bombardier C, Furst D, Goldsmith C, Katz LM, Lightfoot R Jr, Paulus H, Strand V, Tugwell P, Weinblatt M, Williams H, Wolfe F, Kieszak S (1995) American College of Rheumatology preliminary definition of improvement in rheumatoid arthritis. Arthritis Rheum 38(6):727-35. https:// doi.org/10.1002/art.1780380602

4. Smolen J, Fleischmann R, Aletaha D, Li Y, Zhou Y, Sainsbury I, Galindo I (2019) Disease activity improvements with optimal discriminatory ability between treatment arms: applicability in early and established rheumatoid arthritis clinical trials. Arthritis Res Ther 21(1):231. https://doi.org/10.1186/s13075-019-2005-9

5. Fleischmann R, van der Heijde D, Koenig AS, Pedersen R, Szumski A, Marshall L, Bananis E (2015) How much does Disease Activity Score in 28 joints ESR and CRP calculations underestimate disease activity compared with the Simplified Disease Activity Index? Ann Rheum Dis 74:1132-1137. https://doi.org/ 10.1136/annrheumdis-2013-204920

6. Taylor P, Keystone E, van der Heijde D, Weinblatt M, Del Carmen M, Reyes Gonzaga J, Yakushin S, Ishii T, Emoto K, Beattie S, Arora V, Gaich C, Rooney T, Schlichting D, Macias W, de Bono S, Tanaka Y (2017) Baricitinib versus placebo or adalimumab in rheumatoid arthritis. N Engl J Med 376(7):652-662. https://doi. org/10.1056/NEJMoa1608345

7. Fleischmann R, Pangan A, Song I, Mysler E, Bessette L, Peterfy C, Durez P, Ostor A, Li Y, Zhou Y, Othman A, Genovese M (2019) Upadacitinib versus placebo or adalimumab in patients with rheumatoid arthritis and an inadequate response to methotrexate: results of a phase 3, double-blind, randomized controlled trial. Arthritis Rheumatol 71(11):1788-1800. https://doi.org/10. 1002/art.41032

8. Combe B, Kivitz A, Tanaka Y, van der Heijde D, Simon J, Baraf H, Kumar U, Matzkies F, Bartok B, Ye L, Guo Y, Tasset C, Sundy J, Jahreis A, Genovese M, Mozaffarian N, Landewe R, Bae S, Keystone E, Nash P (2021) Ann Rheum Dis 80(7):848-858. https://doi.org/10.1136/annrheumdis-2020-219214
9. Fleischmann R, Mysler E, Hall S, Kivitz A, Moots R, Luo Z, DeMasi R, Soma K, Zhang R, Takiya L, Tatulych S, Mojcik C, Krishnaswami S, Menon S, Smolen J (2017) Efficacy and safety of tofacitinib monotherapy, tofacitinib with methotrexate, and adalimumab with methotrexate in patients with rheumatoid arthritis (ORAL Strategy): a phase 3b/4, double-blind, head-tohead, randomised controlled trial. Lancet 390:457-468. https:// doi.org/10.1016/S0140-6736(17)31618-5

10. Rubbert-Roth A, Enejosa J, Pangan A, Boulos H, Rischmueller M, Khan N, Zhang Y, Martin N, Xavier R (2020) Efficacy and safety of upadacitinib versus abatacept in patients with active rheumatoid arthritis. N Engl J Med 383:1511-1521. https://doi. org/10.1056/NEJMoa2008250

11. Strand V, Mysler E, Moots R, Wallenstein G, DeMasi R, Gruben D, Soma K, Iikuni N, Smolen J, Fleischmann R (2019) Patientreported outcomes for tofacitinib with and without methotrexate, or adalimumab with methotrexate, in rheumatoid arthritis: a phase IIIB/IV trial. RMD Open 5(2):e001040. https://doi.org/ 10.1136/rmdopen-2019-001040

12. Keystone E, Taylor P, Tanaka Y, Gaich C, DeLozier A, Dudek A, Zamora J, Covarrubias Cobos J, Rooney T, de Bono S, Arora V, Linetzky B, Weinblatt M (2017) Patient-reported outcomes from a phase 3 study of baricitinib versus placebo or adalimumab in rheumatoid arthritis: secondary analyses from the RA-BEAM study. Ann Rheum Dis 76:1853-1861. https://doi. org/10.1136/annrheumdis-2017-211259

13. Taylor PC, Lee YC, Fleischmann R, Takeuchi T, Perkins E, Fautrel B, Zhu B, Quebe A, Gaich C, Zhang X, Dickson C, Schlichting D, Patel H, Durand F, Emery P (2019) Achieving pain control in rheumatoid arthritis with baricitinib or adalimumab plus methotrexate: results from the RA-BEAM trial. J Clin Med 8(6):831. https://doi.org/10.3390/jcm8060831

14. Fautrel B, Kirkham B, Pope J, Takeuchi T, Gaich C, Quebe A, Zhu B, de la Torre De, Leonardis F, Taylor P (2019) Effect of baricitinib and adalimumab in reducing pain and improving function in patients with rheumatoid arthritis in low disease activity: exploratory analyses from RA-BEAM. J Clin Med 8(9):1394. https://doi.org/10.3390/jcm8091394

15. Lee E, Fleischmann R, Hall S, Wilkinson B, Bradley J, Gruben D, Koncz T, Krishnaswami S, Wallenstein G, Zang C, Zwillich S, van Vollenhoven R, for the ORAL Start Investigators, (2014) Tofacitinib versus methotrexate in rheumatoid arthritis. N Engl J Med 370:2377-2386. https://doi.org/10.1056/NEJMoa1310 476

16. Fleischmann R, Schiff M, van der Heijde D, Ramos-Remus C, Spindler A, Stanislav M, Zerbini CA, Gurbuz S, Dickson C, de Bono S, Schlichting D, Beattie S, Kuo WL, Rooney T, Macias W, Takeuchi T (2017) Baricitinib, methotrexate, or combination in patients with rheumatoid arthritis and no or limited prior diseasemodifying antirheumatic drug treatment. Arthritis Rheumatol 69(3):506-517. https://doi.org/10.1002/art.39953

17. van Vollenhoven R, Takeuchi T, Pangan A, Friedman A, Mohamed M, Chen S, Rischmueller M, Blanco R, Xavier R, Strand V (2020) Efficacy and safety of upadacitinib monotherapy in methotrexate-naive patients with moderately-to-severely active rheumatoid arthritis (SELECT-EARLY): a multicenter, multicountry, randomized, double-blind, active comparator-controlled trial. Arthritis Rheumatol 72(10):1607-1620. https://doi.org/10. 1002/art.41384

18. Westhovens R, Rigby W, van der Heijde D, Ching D, Stohl W, Kay J, Chopra A, Bartok B, Matzkies F, Yin Z, Guo Y, Tasset C, Sundy J, Jahreis A, Mozaffarian N, Messina O, Landewe R, Atsumi T, Burmester G (2021) Filgotinib in combination with methotrexate or as monotherapy versus methotrexate monotherapy in patients with active rheumatoid arthritis and limited or no prior exposure to methotrexate: the phase 3 , randomised controlled 
FINCH 3 trial. Ann Rheum Dis 80(6):727-738. https://doi.org/ 10.1136/annrheumdis-2020-219213

19. Burmester G, Rigby W, van Vollenhoven R, Kay J, Rubbert-Roth A, Kelman A, Dimonaco S, Mitchell N (2016) Tocilizumab in early progressive rheumatoid arthritis: FUNCTION, a randomised controlled trial. Ann Rheum Dis 75:1081-1091. https://doi.org/ 10.1136/annrheumdis-2015-207628

20. Klareskog L, van der Heijde D, de Jager J, Gough A, Kalden J, Malaise M, Martin-Mola E, Pavelka K, Sany J, Settas L, Wajdula J, Pedersen R, Fatenejad S, Sanda M (2004) Therapeutic effect of the combination of etanercept and methotrexate compared with each treatment alone in patients with rheumatoid arthritis: doubleblind randomised controlled trial. Lancet 363(9410):675-681. https://doi.org/10.1016/S0140-6736(04)15640-7

21. Breedveld F, Weisman M, Kavanaugh A, Cohen S, Pavelka K, van Vollenhoven R, Sharp J, Perez J, Spencer-Green G (2006) The PREMIER study: a multicenter, randomized, double-blind clinical trial of combination therapy with adalimumab plus methotrexate versus methotrexate alone or adalimumab alone in patients with early, aggressive rheumatoid arthritis who had not had previous methotrexate treatment. Arthritis Rheum 54(1):26-37. https://doi. org/10.1002/art.21519

22. Emery P, Fleischmann R, Moreland L, Hsia E, Strusberg I, Durez P, Nash P, Amante E, Churchill M, Park W, Pons-Este B, Doyle M, Visvanathan S, Xu W, Rahman M (2009) Golimumab, a human anti-tumor necrosis factor alpha monoclonal antibody, injected subcutaneously every four weeks in methotrexate-naive patients with active rheumatoid arthritis: twenty-four-week results of a phase III, multicenter, randomized, double-blind, placebocontrolled study of golimumab before methotrexate as first-line therapy for early-onset rheumatoid arthritis. Arthritis Rheum 60(8):2272-2283. https://doi.org/10.1002/art.24638

23. Emery P, Burmester G, Bykerk V, Combe B, Furst D, Barre E, Karyekar C, Wong D, Huizinga T (2015) Evaluating drug-free remission with abatacept in early rheumatoid arthritis: results from the phase $3 b$, multicentre, randomised, active-controlled AVERT study of 24 months, with a 12-month, double-blind treatment period. Ann Rheum Dis 74(1):19-26. https://doi.org/ 10.1136/annrheumdis-2014-206106

24. Burmester GR, Blanco R, Charles-Schoeman C, Wollenhaupt J, Zerbini C, Benda B, Gruben D, Wallenstein G, Krishnaswami S, Zwillich S, Koncz T, Soma K, Bradley J, Mebus C (2013) Tofacitinib (CP-690,550) in combination with methotrexate in patients with active rheumatoid arthritis with an inadequate response to tumour necrosis factor inhibitors: a randomised phase 3 trial. Lancet 381(9865):451-460. https://doi.org/10.1016/S0140-6736(12) 61424-X

25. Genovese M, Kremer J, Zamani O, Ludivico C, Krogulec M, Xie L, Beattie S, Koch A, Cardillo T, Rooney T, Macias W, de Bono
S, Schlichting D, Smolen J (2016) Baricitinib in patients with refractory rheumatoid arthritis. N Engl J Med 374:1243-1252. https://doi.org/10.1056/NEJMoa1507247

26. Genovese M, Fleischmann R, Combe B, Hall S, Rubbert-Roth A, Zhang Y, Zhou Y, Mohamed M, Meerwein S, Pangan A (2018) Safety and efficacy of upadacitinib in patients with active rheumatoid arthritis refractory to biologic disease-modifying anti-rheumatic drugs (SELECT-BEYOND): a double-blind, randomised controlled phase 3 trial. Lancet 391(10139):2513-2524. https:// doi.org/10.1016/S0140-6736(18)31116-4

27. Fleischmann R, Genovese M, Enejosa J, Mysler E, Bessette L, Peterfy C, Durez P, Ostor A, Li Y, Song I (2019) Safety and effectiveness of upadacitinib or adalimumab plus methotrexate in patients with rheumatoid arthritis over 48 weeks with switch to alternate therapy in patients with insufficient response. Ann Rheum Dis 78(11):1454-1462. https://doi.org/10.1136/annrh eumdis-2019-215764

28. Genovese M, Kalunian K, Gottenberg J, Mozaffarian N, Bartok B, Matzkies F, Gao J, Tasset C, Sundy J, de Vlam K, Walker D, Takeuchi T (2019) Effect of filgotinib vs placebo on clinical response in patients with moderate to severe rheumatoid arthritis refractory to disease-modifying antirheumatic drug therapy: the FINCH 2 randomized clinical trial. JAMA 322(4):315-325. https://doi.org/10.1001/jama.2019.9055

29. Huffstutter J, Kafka S, Brent L, Matucci-Cerinic M, Tang K, Chevrier M, Sprabery T, DeHoratius R (2017) Clinical response to golimumab in rheumatoid arthritis patients who were receiving etanercept or adalimumab: results of a multicenter active treatment study. Curr Med Res Opin 33(4):657-666. https://doi.org/ 10.1080/03007995.2016.1277195

30. Smolen J, Burmester G.R. Combe B, Curtis J.R, Hall S, Haraoui B, van Vollenhoven R, Cioffi, C, Ecoffet C, Gervitz L, Ionescu L, Peterson L, Fleischmann R (2016) Head-to-head comparison of certolizumab pegol versus adalimumab in rheumatoid arthritis: 2-year efficacy and safety results from the randomised EXXELERATE study. Lancet 388(10061);2763-2774 doi: https://doi.org/ 10.1016/S0140-6736(16)31651-8.

31. PRAC recommendations on signals EMA/PRAC/319259/ July 2021: https://www.ema.europa.eu/en/documents/prac-recom mendation/prac-recommendations-signals-adopted-7-10-june2021-prac-meeting_en.pdf. Accessed 12 Sep 2021

Publisher's note Springer Nature remains neutral with regard to jurisdictional claims in published maps and institutional affiliations. 